\title{
PERILAKU MAHASISWI DALAM PERAWATAN KECANTIKAN SECARA TRADISIONAL
}

\author{
Indarto AS, Nutrisia Aquariushinta Sayuti, Atik Riwati \\ Kementerian Kesehatan Politeknik Kesehatan Surakarta Jurusan Jamu
}

\begin{abstract}
Behavior, Young Women, Traditional Beauty Care. This study aims to reveal the behavior of a student in a traditional beauty treatments. This study used a qualitative design with sampling technique is purposive sampling and the type of maximum variation sampling. Collecting data using Focus Group Discussion and Interview depth. This study uses 6 informant DKT and 2 informants WM. Test the validity of the data was done by using triangulation. The results showed that most informants understand the sense of beauty treatments and traditional, benefits and problems on the part of the body, the informant also shows a good attitude to the traditional beauty treatments, and the attitude of informants in beauty treatments traditionally reaches levels responsible attitude. Activity informant in beauty treatments has traditionally been reached on the level of activity adoption.
\end{abstract}

Keywords: Behavior, Young Women, Traditional Beauty Care

\begin{abstract}
Abstrak: Perilaku, Remaja Putri, Perawatan Kecantikan Tradisional. Penelitian ini bertujuan untuk mengungkap perilaku mahasiswi dalam perawatan kecantikan secara tradisional. Penelitian ini menggunakan rancangan kualitatif dengan teknik sampling secara purposive sampling dan jenis maximum variation sampling. Pengumpulan data menggunakan Diskusi Kelompokkan Terarah dan Wawancara Mendalam. Penelitian ini menggunakan 6 informan DKT dan 2 informan WM. Uji keabsahan data dilakukan dengan teknik triangulasi. Hasil penelitian menunjukkan bahwa sebagian informan mengerti tentang pengertian perawatan dan kecantikan secara tradisional, manfaat dan masalah pada bagian tubuh, informan juga menunjukkan sikap baik pada perawatan kecantikan secara tradisional, dan sikap informan dalam perawatan kecantikan secara tradisional mencapai tingkatan sikap bertanggungjawab. Aktivitas informan dalam perawatan kecantikan secara tradisional sudah mencapai pada tingkatan aktivitas adopsi.
\end{abstract}

Kata Kunci: Perilaku, Remaja Putri, Perawatan Kecantikan Tradisional

\section{PENDAHULUAN}

Masa remaja merupakan masa transisi atau masa peralihan dari masa kanak-kanak menuju masa dewasa yang ditandai adanya perubahan fisik, mental, nilai, dan minat-minat baru. Pada masa ini para remaja akan menimbulkan perilaku-perilaku yang mengarah pada keinginan untuk menonjolkan diri terutama pada perilaku untuk merubah diri. Salah satu aspek psikologis dari perubahan fisik pada masa pubertas adalah remaja menjadi amat memperhatikan tubuh mereka dan membangun citranya sendiri mengenai bagaimana tubuh mereka tampaknya ( Herlock,2006 dan Santrock,2005 dalam Pramita,2010). 
Perilaku dapat diartikan sebagai suatu aksi dan reaksi organisme terhadap lingkungan. Hal ini berarti bahwa perilaku baru terjadi apabila ada sesuatu yang diperlukan untuk menimbulkan reaksi, yakni yang disebut rangsangan. Dengan demikian, suatu rangsangan tertentu akan menghasilkan reaksi atau perilaku tertentu termasuk perilaku untuk tampil cantik dikalangan remaja putri (Notoadmojo, 2012).

Kecantikan sudah berubah karena pengaruh kapitalisme global. Kulit yang putih, rambut yang panjang dan lurus, sampai berbagai obat dan cara pengurusan tubuh yang menjadi ikon kecantikan masyarakat barat berpengaruh di Indonesia. Kenyataan bahwa masyarakat Indonesia yang berkulit sawo matang telah dipengaruhi oleh budaya barat sehingga terjadinya penggeseran dari kecantikan asli Indonesia itu sendiri.

Dari studi pendahuluan yang dilakukan pada tanggal 24 Maret 2014 di Kampus III Poltekkes Surakarta didapatkan data bahwa tidak semua mahasiswi yang disurvei melakukan perawatan diri dengan cara tradisional. Perawatan kecantikan secara tradisional menurut para mahasiswi sulit dilakukan karena terlalu rumit dan tidak ada waktu. Terdapat 8 orang mahasiswa yang aktif merawat diri dengan perawatan kecantikan secara tradisional. Oleh karena itu, penelitian ini hanya dilakukan pada mahasiswi yang aktif melakukan perawatan kecantikan tradisional tersebut dengan mengobservasi perilaku mereka. Berdasarkan latar belakang diatas peneliti tertarik melakukan penelitian tentang "Perilaku mahasiswi Surakarta dalam melakukan perawatan kecantikan secara tradisional di Kampus III Poltekkes Surakarta".

\section{METODE PENELITIAN}

Jenis penelitian ini adalah deskriptif kualitatif, yaitu metode penelitian naturalistik karena penelitiannya diambil pada kondisi yang alamiah. Metode penelitian ini digunakan untuk meneliti kondisi obyek yang alamiah ,tidak ada manipulasi data oleh peneliti sehingga kondisi tidak berubah baik saat peneliti memasuki obyek, setelah berada di obyek ataupun setelah berada diluar obyek ( Sugiyono, 2014). Peneliti ingin mengetahui perilaku mahasiswi Kampus III Poltekkes Surakarta yang melakukan perawatan kecantikan secara tradisional tentang pengetahuan, sikap dan aktivitas meraka dalam melakukan perawatan kecantikan secara tradisional.

Teknik pengumpulan dengan melakukan diskusi kelompok terarah (DKT) dan wawancara mendalam (WM). Alat yang digunakan adalah panduan DKT dan WM yang digunakan untuk meneliti fenomena berupa perilaku mahasiswi di Kampus III Poltekkes Surakarta dalam perawatan kecantikan secara tradisional dengan subfenomena pengetahuan, sikap dan aktivitas mahasiswi di Kampus III Poltekkes Surakarta dalam perawatan kecantikan secara tradisional. Tape Recorder atau Sound recorder digunakan untuk merekam semua pendapat yang disampaikan oleh responden. Buku catatan dan alat tulis juga digunakan dalam penelitian. Kamera untuk mendokumentasikan hasil observasi.

Populasi pada penelitian ini adalah semua mahasiswi remaja di kampus III Poltekkes Surakarta tahun 
ajaran 2012 /2013 yang berjumlah 327 mahasiswa putri. Jumlah informan dalam penelitian kualitatif tidak dapat direncanakan secara pasti karena salah satu tujuannya adalah memperoleh variasi sebanyak-banyaknya, pemilihan informan berakhir bila sudah terjadi pengulangan (Moleong, 2007). Teknik pengambilan sample dalam penelitian ini adalah purposive sampling dengan jenis maximum variation sampling yaitu menentukan sample dengan pertimbangan tertentu yang dianggap dapat memberikan data secara maksimal sehingga akan memudahkan peneliti menjelajahi obyek yang diteliti (Sugiyono, 2014). Pada teknik ini informan ditentukan oleh pertimbangan-pertimbangan informasi yang diperlukan dan jika tidak ada lagi informasi yang dapat dijaring, maka penarikan informan sudah dapat diakhiri (Moleong, 2007). Informan yang digunakan dalam penelitian ini adalah remaja putri Kampus III Politekkes Surakarta Klaten yang memenuhi kriteria inklusi yaitu berusia antara 16-19 tahun, aktif melakukan perawatan kecantikan secara tradisional dan bersedia menjadi informan penelitian. Dengan teknik pengambilan sampel tersebut didapatkan 8 orang mahasiswi yang aktif melakukan perawatan kecantikan tradisional dan bersedia menjadi informan. Penulis menggunakan teknik DKT yang dilakukan dua kali dan WM yang dilakukan dua kali, dimana jumlah remaja yang mengikuti DKT sebanyak 6 orang dan yang mengikuti WM sebanyak 2 orang.

Jalannya penelitian secara umum dibedakan menjadi tiga tahap, yaitu tahap pralapangan, tahap pekerjaan lapangan, dan tahap analisis data. Kegiatan yang dilakukan dalam tahap pralapangan adalah mengurus perijinan dan melihat keadaan lapangan. Tahaptahap dalam pekerjaan lapangan dengan etika penelitian antara lain :

a. Menyusun rancangan proposal penelitian dan panduan WM dan DKT dan melakukan uji coba panduan tersebut.

b. Memilih informan dan menyiapkan peralatan penelitian

c. Melakukan perkenalan peneliti dan asisten peneliti serta melakukan pendekatan dengan informan.

d. Melakukan DKT, WM, dan observasi kegiatan sehari-hari informan.

e. Melakukan open coding, pengkategorian data (core category), theoritical coding dan analisis untuk mendapatkan kesimpulan sementara tentang kelengkapan atau kekurangan data DKT dan WM yang dihasilkan. Bila ada kekurangan data, maka dilakukan pencarian data kembali setelah instrument diperbaiki.

f. Analisis data hasil wawancara dan observasi secara deskriptif.

Setiap fenomena penelitian dilakukan analisis isi (content analysis) yang merupakan teknik sistematik untuk menganalisa makna pesan dan mengungkapkan pesan berdasarkan data yang didapat. Analisis ini melibatkan kegiatan dengan mengembangkan, membandingkan, serta membedakan dengan penemuan dari berbagai teori dan kriteria. Adapun tujuan dari analisis ini adalah untuk membuat suatu intervensi yang dihubungkan 
dengan teori dalam penelitian. Analisis data yang digunakan dalam penelitian ini adalah interactive model Miles dan Hubberman (1984) dalam Sugiyono (2014) yang terdiri dari empat langkah yang saling berkaitan, yaitu :1. pengumpulan data; 2. Penyederhanaan atau reduksi data; 3 . penyajian data(data display);4. Penarikan kesimpulan dan verifikasi.

g. Melakukan uji keabsahan data dengan uji kepercayaan (creadibility) yaitu trianggulasi dan pengecekan anggota (member checking) dan uji kebergantungan (depenability).

Tahap pasca lapangan yang akan dilakukan adalah peneliti menyusun hasil penelitian dan menyajikan hasil penelitian dengan melakukan seminar penelitian.

\section{HASIL PENELITIAN}

Penelitian ini menunjukkan bahwa sebagian informan mengerti tentang pengertian perawatan dan kecantikan secara tradisional, manfaat dan masalah pada bagian tubuh. Sebagian informan menunjukkan sikap baik pada perawatan kecantikan secara tradisional. Aktifitas sebagian besar informan sudah melakukan perawatan secara tradisional.

\section{PEMBAHASAN}

Berdasarkan hasil penelitian, informan berpendapat bahwa perawatan kecantikan wanita adalah usaha usaha wanita menjaga diri atau merawat diri agar tetap bersih dan cantik, sempurna dan juga dapat memperbaiki atau melengkapi kekurangannya sehingga timbul proses diri menjadi lebih baik dalam hal merawat, menjaga kecantikan, keindahan dan kesempurnaan wanita. Pengertian dari kecantikan wanita yang di dapat dari informan adalah kecantikan dari fisik yaitu kecantikan dari luar seperti kulit terawat, bersih dan tidak harus putih serta kecantikan dari hati seperti baik hati, tidak sombong, dengki, dan iri. Ada informan yang mengatakan bahwa kecantikan itu bersifat relatif. Orang dikatakan cantik jika memang orang lain berpandangan bahwa wanita itu cantik. Dalam hal ini, pemilihan kriteria cantik bagi satu orang dengan yang lain berbeda. Perbedaan pendapat tersebut membuat nilai kecantikan tidak dapat diukur dengan jelas.

Pengetahuan adalah hasil dari tahu yang terjadi setelah seseorang melakukan pengindraan pada obyek tertentu melalui penglihatan dan pendengaran. Berdasarkan hasil penelitian mengenai pengetahuan remaja putri tentang pengertian perawatan dan kecantikan maka didapatkan hasil semua informan dapat mengidentifikasi pengertian perawatan dan pengertian kecantikan dengan baik. Hal ini sesuai dengan teori yang disebutkan Rostamailis (2005) yang menyatakan bahwa pengetahuan tentang perawatan kecantikan adalah suatu ilmu dan keterampilan yang mempelajari bagaimana merawat bagian-bagian badan, sehingga bagianbagian tersebut tidak mengalami perubahan-perubahan yang fatal atau merusak penampilan.

Jawaban informan mengenai pembagian kecantikan menjadi kecantikan dari fisik, hati, sifat wanita dan kecantikan relative sesuai dengan teori yang disebutkan oleh Syata (2012) yang menyatakan bahwa 
terdapat kecantikan luar (outer beauty) yang menyangkut fisik, seperti kulit, wajah, dan bentuk; tetapi yang lebih penting lagi adalah kecantikan dalam (inner beauty) yang berhubungan dengan seluruh kepribadian dan dimensi psikis-rohani dan lebih abadi sifatnya. Akan tetapi terdapat pendapat yang dikemukakan oleh informan yang belum ditemukan di dalam teori yaitu kecantikan adalah kesempurnaan. Kesempurnaan di sini tentu sangat bertolak belakang dengan jawaban informan mengenai kecantikan itu relative karena yang dianggap sempurna oleh satu orang belum tentu sempurna bagi orang lain.

Jawaban informan tentang pengetahuan remaja putri dalam perawatan kecantikan secara tradisional dibagi menjadi 4 kategori. Kategori pertama tentang pengertian perawatan secara tradisional meliputi 6 sub kategori. Sub kategori pertama mengenai perawatan dengan bahan tradisional seperti herbal dan rempah, sub kategori yang kedua yaitu perawatan tanpa zat kimia dan tanpa bahan modern, sub kategori yang ketiga yaitu perawatan dengan bahan olahan sendiri dengan alat yang masih tradisional, sub kategori yang keempat yaitu perawatan tanpa teknologi canggih, sub kategori yang kelima yaitu perawatan tanpa menggunakan produk olahan pabrik dan sub ketegori yang terakhir yaitu perawatan dengan adat-adat.

Kategori kedua tentang manfaat perawatan kecantikan secara tradisional untuk kecantikan dan kesehatan. Kategori ketiga tentang jenis perawatan kecantikan secara tradisional dari dalam tubuh meliputi perawatan dengan jamu dan buah, rajin berolahraga dan sering minum air putih. Kategori terakhir tentang jenis perawatan secara tradisional dari luar tubuh meliputi perawatan dengan masker, totok wajah, facial, dan akupuntur.

Hal ini sesuai dengan teori yang disebutkan Adijaya (2014) dan Rostamailis (2012) yang menyatakan bahwa perawatan tradisional mengutamakan penggunaaan bahanbahan alami yang berasal dari alam sedangkan jenis perawatannya ada yang dari luar dan dari dalam misalnya melangsingkan tubuh dapat dilakukan dengan meminum jamu dan jus buahbuahan dan perawatan dari luar dapat digunakan buah-buahan seperti buah alpukat, timun, tomat, dan pepaya yang dijadikan masker, sedangkan untuk menjaga kebugaran dan kesehatan tubuh dapat dilakukan dengan rajin berolahraga.

\section{KESIMPULAN DAN SARAN}

Pengetahuan mahasiswi dalam melakukan perawatan kecantikan secara tradisional mencapai pada tingkatan pengetahuan aplikasi yaitu mampu menggunakan materi yang telah dipelajari pada kondisi sebenarnya. Sikap informan dalam penelitian ini sudah mencapai tingkatan sikap bertanggung jawab dalam melakukan perawatan kecantikan secara tradisional. Aktivitas informan dalam melakukan perawatan kecantikan secara tradisional sudah mencapai pada tingkatan aktivitas adopsi yaitu sudah mempraktekkan dan melakukan tindakan yang sudah berkembang dengan baik tanpa mengurangi kebenaran tindakan tersebut. 
DAFTAR RUJUKAN

Adijaya (2014). Rahasia Cantik. Solo :

Tiga Serangkai.

Moloeng, Lexy J. (2010). Metodologi Penelitian Kualitatif edisi Revisi. Bandung : PT. Remaja Rosda Karya.

Notoadmojo (2012). Promosi Kesehatan dan Perilaku Kesehatan Edisi Revisi. Jakarta : Rineka Cipta.
Salika. (2010). Serba-serbi Kesehatan Perempuan. Jakarta : Bukune.

Sugiyono. (2014). Memahami Penelitian Kualitatif. Bandung : Alfabeta.

Syata. (2010). Makna Cantik di Kalangan Mahasiswa dalam Perspektif Fenomenologi. Skripsi. Fakultas Ilmu Sosial dan Ilmu Politik. Universitas Hasanudin 